\title{
The Comparative Effect of Teaching Metacognitive Strategies and Collaborative Strategic Reading on EFL Learners' Reading Comprehension
}

\author{
Mania Nosratinia \\ Islamic Azad University at Central Tehran, Iran \\ Elham Mohammadi (Corresponding author) \\ Islamic Azad University at Central Tehran, Iran \\ E-mail: elimmd88@yahoo.com
}

Received: 14-11-2016

Published: 01-05-2017
Accepted: 14-01-2017

doi:10.7575/aiac.ijalel.v.6n.3p.158
Advance Access Published: March 2017

URL: http://dx.doi.org/10.7575/aiac.ijalel.v.6n.3p.158

\begin{abstract}
This study was an attempt to systematically investigate the comparative impact of teaching Metacognitive Strategies (MS) and Collaborative Strategic Reading (CSR) on English as a Foreign Language (EFL) learners' Reading Comprehension (RC). The participants were 58 homogenized intermediate level female EFL learners, within the age range of 18-30 $\left(M_{\text {age }}=24\right)$; they were non-randomly selected and were randomly assigned into two experimental groups of 29. One experimental group received MS training based on Anderson's (2002) model, and the other experimental group received training in CSR based on Klingner and Vaughn's (1998) model. Inspecting the initially-homogenized participants' post-treatment performance, through using a piloted PET reading test and running an independent-samples $t$-test, revealed that the MS group performed significantly better than the CSR group in terms of RC. The study concludes with a discussion on the obtained results, followed by presenting some implications for EFL teachers, EFL learners, and EFL material developers.
\end{abstract}

Keywords: collaborative strategic reading, metacognitive strategies, reading comprehension, strategy training

\section{Introduction}

Reading, functioning as a major channel for receiving information, has always been connected with knowledge acquisition, maturation of thoughts, and advancement; furthermore, among the different components of language proficiency, Reading Comprehension (RC) is one of the most essential skills for English as a Foreign Language (EFL) learners (Lightbown \& Spada, 2013). Regarding the pedagogical concerns, testing RC is one of the measures for estimating the degree of pedagogical success, stated to be a valid measure for evaluating EFL learners' achievement (Harmer, 2007). That is why the English Language Teaching (ELT) domain is now witnessing a growing demand for introducing effective reading instruction techniques and strategies for developing RC (Erten \& Topkaya, 2009; Nosratinia, Mirzakhani \& Zaker, 2013).

It has been stated that in addition to linguistic knowledge, topic familiarity, and general experience, the cognitive skills readers possess and use significantly correlate with their RC in general, especially in ELT contexts and when dealing with numerous intensive reading tasks (Anastasiou \& Griva, 2009). These cognitive skills are believed to develop through training readers in using different strategies (McNamara, 2007). Furthermore, numerous studies have reported that once language learners' awareness of reading strategies improves, their reading performance also improves (Fuchs, \& Fuchs, 2005; McNamara, 2007; Ozgungor \& Guthrie, 2004). Based on this premise, ELT programs are now encouraging the use of strategies in mastering language skills, including RC (Oxford, 1990), and ELT textbooks now include strategy use for developing RC (Lehr, Osborn, \& Hiebert, 2005). Similarly, researchers are now paying more attention to teaching RC strategies (Murphy, Wilkinson, Soler, Hennessey, \& Alexander, 2009).

According to Chamot (2004), learning strategies are "the conscious thoughts and actions that learners take in order to achieve a learning goal" (p. 14). Among the strategies introduced for developing RC, Collaborative Strategic Reading (CSR), introduced by Klingner and Vaughn (1998), has proven to significantly contribute to EFL learners' RC (Katims \& Harmen, 2000; Nosratinia et al., 2013; Wang, 2008). The CSR principles seem to be rooted in valuing cooperation and employing a combination of strategies simultaneously (Nosratinia et al., 2013; Standish, 2005). CSR was designed to facilitate RC for students who have different reading problems (Klingner \&Vaughn, 2000).

CSR combines cooperative learning and RC strategy instruction (Grabe, 2009). Using CSR, L2 learners work in groups, activate their prior knowledge, make predictions, monitor their comprehension difficulties, clarify information, restate significant points, summarize the text, and form proper questions about the text (Grabe, 2009). In practice, the strategies 
implemented in CSR practice are: (a) preview (before reading), (b) click \& clunk (during reading), (c) get the gist (during reading), and (d) wrap-up (after reading) (Vaughn \& Klingner, 2000).

Preview, happening before reading actually begins, intends to kindle readers' interest in reading, to activate their background knowledge, and make them more focused. Click and clunk, taking place during the reading process, intends to enable the readers to monitor their own reading performance. Click and Clunk is stated o be a self-monitoring and metacognitive strategy (Vaughn \& Klingner, 1999). Get the gist, also happening during the reading process, aims to enable the reader to determine the main idea. Finally, wrap-up, as a post-reading activity, intends to enable the reader to review what they have read and review their understanding. This activity, according to Palincsar and Brown (1984), is also a metacognitive and comprehension monitoring strategy as it highlights self-evaluation.

Table 1. Steps in Collaborative Strategic Reading

\begin{tabular}{ll}
\hline CSR Strategies & \multicolumn{1}{c}{ Procedure and Steps } \\
\hline Preview & Brainstorming: Think about what you already know about the topic. \\
(before reading) & Predicting: Find clues in the title, subheadings, or pictures about \\
what you will learn. Skim the text for keywords that might give you \\
hints.
\end{tabular}

CSR applies the principles of cooperative learning (Vaughn \& Klingner, 2000) by creating meaningful roles for the participants. Therefore, before the learners take up their role for CSR, they have the chance to practice the specific responsibilities associated with their roles. The CSR guidelines propose six roles, namely leader, clunk expert, gist expert, encourager, announcer and timekeeper. Of those six roles, leader, clunk expert and gist expert are essential; however, the other three roles can be combined or assigned more flexibly (Klingner \& Vaughn, 1998).

Besides CSR, Metacognitive Strategies (MS) are believed to be highly crucial and effective in L2 learning (Anderson, 1991; Huang \& Newbern, 2012). The term "metacognition" has been defined as the capacity to regulate one's cognitive learning activities, acting at a meta-level (Efklides, 2006). According to Flavell (1976, as cited in Wong, 1985), MS deal with "one's knowledge concerning one's own cognitive processes and products" (p. 232). MS include "planning for learning, monitoring of comprehension or production while it is taking place, and self-evaluation after the learning activity has been completed" (O'Malley \& Chamot 1990, p. 8).

Based on O'Malley, Chamot, Stewner-Manzanares, G., Kupper, L. J., and Russo's (1985) classification, advance organizers, directed attention, selective attention, self-management, functional planning, self-monitoring, delayed production, and self-evaluation are included among the major MS.

MS which are applied in RC, are consist of planning for learning, thinking about the process of learning, selfmanagement, self-monitoring, directed attention, observing, correcting one's comprehension or production, direct attention and evaluating at the different learning phases, for example, before, during, and after learning (O'Malley et al., 1985). Table 2 presents some of the main examples of MS involved in learning. 
Table 2. Examples of Metacognitive Strategies (as cited in Rashtchi \& Keyvanfar, 2010, p. 181)

\begin{tabular}{|c|c|}
\hline Metacognitive strategies & Implementation \\
\hline $\begin{array}{l}\text { Planning and organizing for } \\
\text { learning }\end{array}$ & $\begin{array}{l}\text { - Previewing the next unit of the course book } \\
\text { - Deciding in advance to pay attention to general } \\
\text { or specific aspects of language input }\end{array}$ \\
\hline $\begin{array}{l}\text { Finding ways to make learning } \\
\text { more effective }\end{array}$ & $\begin{array}{l}\text { - } \quad \text { Making word cards } \\
\text { - } \quad \text { Categorizing words in semantic groups }\end{array}$ \\
\hline Self-monitoring while learning & $\begin{array}{l}\text { - Reviewing one's notes while studying } \\
\text { - Monitoring one's production of tenses while } \\
\text { speaking }\end{array}$ \\
\hline $\begin{array}{l}\text { Evaluating one's work on } \\
\text { language }\end{array}$ & $\begin{array}{l}\text { - Reading the teacher's comments and } \\
\text { corrections on a written work } \\
\text { - Checking one's writing for accuracy }\end{array}$ \\
\hline
\end{tabular}

The significant impact of MS on developing language skills has been confirmed in previous research (Nosratinia, Ghavidel, \& Zaker, 2015). These strategies have been stated to enable L2 learners to monitor the learning process and act more autonomously (Hauck, 2005; O'Malley et al., 1985). As stated by Anderson (2002), using MS would result in developed thinking and better learning. Moreover, concerning RC, MS have been considered the most important set of strategies (Anderson, 2005).

Although many studies have highlighted the significance of strategy training in developing language skills, especially $\mathrm{RC}$, in reality, little strategy training is taking place in ELT contexts (Zahedi \& Dorrimanesh, 2008), and in many cases, the strategy training is not that effective (Carnine \& Carnine, 2004; Griffiths, 2008; Tsao, 2004). Furthermore, many ELT practitioners are concerned about the effectiveness of the available strategic frameworks. However, there seems to be a dearth of studies which compare the effectiveness of different strategy training models. As a result, the comparative effectiveness of these training models is unbeknownst to language educators. Rooted in the abovementioned premises, this study aimed at conducting a systematic comparison between CSR and MS training for developing EFL learners' RC. To fulfill this purpose, the following research question was formulated:

$$
\text { Is there any significant difference between the effect of teaching CSR and MS on EFL learners' RC? }
$$

\section{Method}

\subsection{Participants}

The participants of this study were58 homogenized intermediate level female EFL learners, within the age range of 18$30\left(M_{\text {age }}=24\right)$ who studied at Iran Mehr language school, Tehran, Iran. These participants were non-randomly selected and homogenized from among 78 EFL learners, employing the Preliminary English Test (PET). The participants whose scores fell within one standard deviation below and above the mean were selected $(n=58)$. They were randomly assigned into two experimental groups of $29, \mathrm{CSR}$ and MS groups.

In addition to the abovementioned individuals, $30 \mathrm{EFL}$ learners, with the same characteristics as the main participants, took part in the piloting of the PET tests, employed as reading pretest and posttests. Furthermore, besides one of the researchers as a teacher and rater, another trained rater who was an MA holder in TEFL with six years of teaching experience participated in the scoring phase of the writing section of the PET test.

\subsection{Instrumentation}

In order to fulfill the purpose of the study, the following instruments were utilized:

- The Preliminary English Test

- The Rating Scale of the Writing Section

- The Course Textbook

- The Learning Logs

- The Cue Cards

- The Handout of Metacognitive Strategies

\subsubsection{The Preliminary English Test (PET)}

In order to check the pre-treatment homogeneity of the participants in terms of general language proficiency, the researcher administered a version of the PET test, adapted from the book PET Practice Test (Quintana, 2008). However, due to some practicality issues, e.g. the institutional rules, only the reading and writing sections of the test were administered. The reading section consists of five parts with $35 \mathrm{RC}$ questions, including multiple-choice, matching, true/false, and four option multiple cloze items. The writing section consists of three parts with 8 questions including, sentence transformation, writing a short message, and writing a letter or a short story. The allocated time for these two sections (i.e. reading and writing) is 1 hour and 30 minutes. 
Following selecting the participants, in order to ensure the pre-treatment homogeneity of the participants in terms of RC in the two experimental groups, their scores of the reading section of the homogenization PET test (with 35 questions; employed earlier) were analyzed. Furthermore, the reading section of another PET test, adapted from the same book, was employed as the posttest. Both of the reading sections were piloted with 30 individuals, and the reliability, item facility, item discrimination, and choice distribution indexes were calculated

\subsubsection{The Rating Scale of the Writing Section}

The analytic writing scale developed by Cambridge under the name of General Mark Schemes for Writing was employed to rate the writing section of the PET in this study. It includes a scale of 0-5 based on content, organization, cohesion, coherence, format, range, mechanical accuracy, word choice, dictation, and sentence structures.

\subsubsection{The Course Textbook}

The course textbook was the American English File (2nd ed.) by Christina Latham-Koenig, Clive Oxenden, and Paul Seligson (2014), published by Oxford University Press. The textbook contains 10 lessons, and each lesson contains all four skills of listening, speaking, reading, and writing and sub skills of grammar, vocabulary, and pronunciation. Four units (units 1 to 4 ) were covered during the course of this study. Each unit contains two readings; therefore, eight readings were covered.

\subsubsection{The Learning Logs}

The learning logs were used in the CSR group in order to serve two purposes: (a) helping learners record their ideas and facilitate cooperative learning, and (b) enabling learners to keep track of learning as it happens. The learning logs ask learners to identify, what they already know about the topic, what they predict they will learn, their questions about the passage, and the gist of the reading.

\subsubsection{The Cue Cards}

The cue cards were given to each member of the CSR to help them stay focused on the task and increase their confidence (Klingner, Vaughn, \& Schumm, 2001). These cards also functioned as reminders, providing information about participants' strategies and roles in the learning process.

\subsubsection{The Handout of Metacognitive Strategies}

Among different types of MS four of them were selected in relation to the course book of this study. Hence, a handout consisting of the four selected MS in details and examples was distributed to the participants in the MS group.

\subsection{Procedure}

The researchers followed certain steps, stated in a chronological order in this section.

\subsubsection{The Pre-Treatment Phase}

Piloting the reading sections of the PET tests was the initial step for implementing this study. These two reading sections were administered separately to 30 non-participating individuals who had almost the same characteristics as the participants of the study. The three characteristics of individual items (item facility, item discrimination, and choice distribution) as well as the reliability indexes (using Cronbach's alpha coefficient; before and after omitting the malfunctioning items.) were calculated. Accordingly, four malfunctioning items were removed from the first (pretest) reading section.

The writing part of the homogenization PET test was rated, using the rating scale of the writing section by the two raters. Calculating the inter-rater reliability indicated that there was an acceptable consistency between the two raters, making it legitimate to use the mean score of the scores given by the two rates as the writing score of each individual. Following this, the piloted PET test was administered to the 78 EFL learners, selected non-randomly. Based on the results, 58 individuals whose scores fell between one standard deviation above and below the mean were selected as the main participants and were randomly assigned to two experimental groups, CSR and MS.

Following assigning of the participants to the two groups, the scores of the reading section of the homogenization PET test were analyzed as the pretest scores in order to ensure the pre-treatment homogeneity of the participants in terms of RC. The two groups were instructed by the same teacher, using the same course textbook. The teacher tried to teach the relevant grammatical points as well as the essential vocabularies alongside of language skills with special focus on the reading skill.

Both experimental groups attended their classes twice a week for 12 sessions during six weeks. Each session took about 90 minutes. The teacher divided the time of the class into two parts. The first part lasted 55 minutes. During this part, she taught the course book to both of the experimental groups in the same way. After a five-minute break, the second part, which lasted for 30 minutes, was devoted to the treatment of RC sections. This part was different in the two experimental groups, explained hereunder.

\subsubsection{The CSR Group}

In the CSR group, the learners were taught reading strategies according to the CSR model proposed by Klingner and Vaughn (1998). The teaching of reading strategies according to CSR occurred in two phases: modeling and cooperative application of strategies. The first phase involved teaching the four strategies of CSR through explicit instruction (4 sessions). The second phase involved teaching students to use cooperative groups efficiently as a means of applying the strategies they learned (Vaughn \& Klinger, 1999). 
In the first phase, the teacher explicitly taught the CSR strategies (preview, click-and-clunk, get the gist, and wrap-up) through four sessions (see Table 1). Each strategy was presented by giving examples. The Preview strategy focused on brainstorming and making predictions. As for the Click and Clunk strategy, the participants were informed that clicks refer to parts of the text that they really get, and clunks were those words, concepts, or ideas that they really did not understand. In the Click and Clunk section, the teacher read a short piece of reading text aloud and asked the students to record clunks in their learning logs. Students then worked together, using fix-up strategies to discover what their clunks mean (see Table 1).

Concerning the Get the Gist strategy, the participants were asked to write out the gist for each paragraph in ten words or less. This was then completed for each of the paragraphs and then students worked in groups to compare their answers. In order to identify the main idea, the learners were asked some questions (see Table 1). Finally, using the Wrap Up strategy, the participants were asked to generate questions about the passage and review the important information in the passage. In doing so, they were also invited to think of questions they would ask if they were the teacher.

In the second phase (after the 4 sessions), having learned the four comprehension strategies, the participants used the strategies in cooperative learning groups. The teacher explained that each student must have a key role to play. These roles, as explained earlier (see introduction) included: Leader, Clunk Expert, Gist Expert, Announcer, Encourager, and Timekeeper (Klingner et al., 2001). In order for the participants to perform their roles properly in the groups, the cue card, describing the roles was given to them. After the participants learned about the roles, the teacher assigned them in groups of three in order to apply the strategies according to the cue cards they had. Exercising the CSR model lasted for six sessions.

\subsubsection{The MS Group}

In the first session of treatment, this group was provided with the explanation of the definition, nature, purpose, importance, and procedures of MS in RC. As stated in the introductory section, numerous MS have been proposed by different individuals and within different frameworks (e.g. O'Malley et al., 1985). Among different types of MS, four of them, proposed by Anderson (2002), were selected which seemed more pertinent and appropriate for this study. Following this, a handout, providing explanations and examples pertinent to the four strategies, was prepared and distributed among the participants. The four selected MS and some of their main components are:
1. Use Background Knowledge
- Attempting to establish the link between the reading and readers' life experience and knowledge,
- Active participation in reading,
- Activating readers' brain and get it ready to learn about the topic,
- Attempting to predict the content of the reading based on the topic and after skimming the text, and
- Checking the accuracy of the predictions at the end.
2. Grasping the Main Idea and Theme
- Getting what is important and ignoring what is not,
- Focusing on important information and excluding peripheral or unimportant details,
- Attempting to understand the relationship between main ideas and details, and
- Listing significant details.
3. Selective Attention
- Promoting the understanding of new information,
- Highlighting only the keywords, phrases, vocabulary, and ideas that are central to understand the reading and important to complete the task,
- Concentrate on the information the reader already knows and key information such as times or dates to understand or communicate better, and
- Moving eyes as quickly as possible down the page to find the clue.
4. Drawing Inferences from Text
- Making connections between personal experiences and the comprehension of a text,
- Reading between the lines,
- Recognizing the author's view of the world,
$\circ$ Looking for pronouns and figuring out what to connect them to,
- Figuring out explanations for the events,
- Making inferences by questioning during the story, e.g. why a character does something, how a character feels, what will happen next and why?

The strategy instruction took four sessions. The teacher tried to provide examples through a reading task to show the students clearly how they are used, and why they are helpful. The participants learned how to implement these strategies based on Anderson's (2002) framework which contains five steps. According to Anderson (2002) all of these five steps in this framework interact with each other. A brief summary of each component is discussed below:

a) Preparing and Planning for Learning

Students were asked to think about what they needed or wanted regarding the targeted goal of reading a text, and how they are going to accomplish it. 
b) Selecting and Using Learning Strategies

In this step, students learned how and when they should apply particular strategies in a given context.

c) Monitoring Strategy Use

In this step, learners are encouraged to direct their own progress. They should pause occasionally while reading and ask themselves questions about what they are doing.

d) Orchestrating Various Strategies

Learners are encouraged to orchestrate the use of more than one strategy. They are encouraged to identify and select alternate strategies when a strategy is not working.

e) Evaluating Strategy Use and Learning

At this step, all the above-mentioned steps are revisited and evaluated. Learners should actively evaluate their reading by means of self-questioning to see whether what they are doing is effective or not.

After the teacher instructed the framework step-by-step through examples, she made the participants employ the model based on the strategies they were taught. While the participants were practicing the model, the teachers' role was to check their performances, and she continued this practice for six sessions until she realized that almost all of the participants could employ the model independently.

\subsubsection{Administering the Posttest}

At the end of the treatment phase, the second piloted PET reading test was administered to the participants in the two experimental groups, results of which were used as the posttest. Through this, the researchers were enabled to inspect and compare the effectiveness of the two treatments, reported in the following section.

\section{Results}

This quasi-experimental study, with the type of treatment as the independent variable and $\mathrm{RC}$ as the dependent variable, aimed at comparing the impact of the two treatments, CSR and MS, on EFL learners' RC. In order to accomplish this purpose, the collected data were analyzed using certain statistical techniques. The analyses and the obtained results are reported in this section.

\subsection{The Pre-Treatment Analyses}

Initially, the homogenized participants had to be selected based on their PET scores. Prior to this selection, a pilot study was conducted in order to inspect the reliability indices and the features of the items in the homogenization PET test and the posttest. These tests were administered to the pilot group $(n=30)$. The item analysis procedure revealed that there were four malfunctioning items (items 13, 25, 34, and 38) in the first PET test. These items were removed. Following this, the internal consistency of the homogenization PET scores in the PET piloting phase was calculated, using Cronbach's alpha coefficient. The obtained value was 0.862 . As for the writing section of the test, running Pearson's product-moment correlation coefficient indicated a significant and positive correlation between the two sets of writing scores, $r=.90, n=30, p<.01$, indicating a high level of inter-rater reliability between the two raters. Regarding the posttest, the analyses indicated that there were no malfunctioning items, and the reliability index was 0.895 .

The piloted PET test was administered among 78 non-randomly selected intermediate EFL learners. The obtained descriptive statistics (Mean $=35.93, S D=7.62$ ) were employed for selecting the homogeneous participants of the study. Those learners whose PET scores fell within the range of -1 SD and +1 SD $(28.32$ to 43.56$)$ were selected $(n=58)$. In order to ensure the pre-treatment homogeneity of the participants in terms of their RC, an independent-samples $t$-test was run between the PET scores of the two experimental groups. The obtained results (Table 3 and Table 4) indicated that there was not a statistically significant difference between the CSR $\left(n=29, M_{C S R}=18.93, S D=3.84\right)$ and MS $(n=$ $\left.29, M_{M S}=19.31, S D=3.69\right)$ participants' pre-treatment RC scores $(t(56)=.383, p=.703$, eta squared $=.0026$ representing a weak effect size).

Table 3. Descriptive Statistics for Pre-Treatment Reading Scores

\begin{tabular}{cccccc}
\hline & Group & N & Mean & Std. Deviation & Std. Error Mean \\
\hline \multirow{2}{*}{ Pretest } & MS & 29 & 19.31 & 3.695 & .686 \\
& CSR & 29 & 18.93 & 3.845 & .714 \\
\hline
\end{tabular}

Table 4. Independent $t$-test on Pre-Treatment Reading Scores

\begin{tabular}{|c|c|c|c|c|c|c|c|c|c|c|}
\hline & & \multicolumn{2}{|c|}{$\begin{array}{c}\text { Levene's Test for } \\
\text { Equality of } \\
\text { Variances }\end{array}$} & \multicolumn{7}{|c|}{ t-test for Equality of Means } \\
\hline & & \multirow[t]{2}{*}{$\mathrm{F}$} & \multirow[t]{2}{*}{ Sig. } & \multirow[t]{2}{*}{$\mathrm{t}$} & \multirow[t]{2}{*}{ df } & \multirow[t]{2}{*}{$\begin{array}{l}\text { Sig. }(2- \\
\text { tailed) }\end{array}$} & \multirow[t]{2}{*}{$\begin{array}{l}\text { Mean } \\
\text { Differen } \\
\text { ce }\end{array}$} & \multirow{2}{*}{$\begin{array}{c}\text { Std. } \\
\text { Error } \\
\text { Differen } \\
\text { ce }\end{array}$} & \multicolumn{2}{|c|}{$\begin{array}{l}\text { 95\% Confidence } \\
\text { Interval of the } \\
\text { Difference }\end{array}$} \\
\hline & & & & & & & & & Lower & Upper \\
\hline \multirow{2}{*}{$\begin{array}{l}\text { Prete } \\
\text { st }\end{array}$} & $\begin{array}{l}\text { Equal variances } \\
\text { assumed }\end{array}$ & .566 & .455 & .383 & 56 & .703 & .379 & .990 & -1.604 & 2.363 \\
\hline & $\begin{array}{l}\text { Equal variances } \\
\text { not assumed }\end{array}$ & & & .383 & $\begin{array}{c}55.91 \\
2\end{array}$ & .703 & .379 & .990 & -1.604 & 2.363 \\
\hline
\end{tabular}




\subsection{Answering the Research Question}

Prior to answering the research question, the assumptions of (a) the dependent variable being measured at the interval or ratio level, (b) random sampling (for assigning the participants to the two groups), and (c) the independence of the subjects were checked and met (Tabachnick \& Fidell, 2007). Furthermore, the normality of the distribution of the scores was checked through checking the descriptive statistics of the experimental groups. The obtained results indicated that the distribution for the posttest scores, along with the pretest scores, was normal as all skewness ratio and kurtosis ratio values fell within the range of -1.96 and +1.96 , supporting the normality of the distribution of the scores (Tabachnick \& Fidell, 2007). The abovementioned results supported the legitimacy of using a parametric statistical test for answering the research question. As the pre-treatment homogeneity of participants in term of their RC was confirmed, an independent-samples $t$-test was run to compare the two groups' means on the RC posttest.

As shown in Table 5, the MS group $\left(n=29, M_{M S}=26.59, S D=3.38\right)$ had a higher mean than the CSR $\left(n=29, M_{C S R}=\right.$ $22.41, S D=3.93$ ) group on the posttest of RC. The obtained results of the independent samples $t$-test are presented in Table 6.

Table 5. Descriptive Statistics of Post-Treatment Reading Scores

\begin{tabular}{llllcc}
\hline & Group & N & Mean & Std. Deviation & Std. Error Mean \\
\hline \multirow{2}{*}{ Posttest } & MS & 29 & 26.59 & 3.386 & .629 \\
& CSR & 29 & 22.41 & 3.933 & .730 \\
\hline
\end{tabular}

Table 6. Independent Samples $t$-Test on Post-Treatment Reading Scores

\begin{tabular}{|c|c|c|c|c|c|c|c|c|c|c|}
\hline & & \multicolumn{2}{|c|}{$\begin{array}{c}\text { Levene's Test for } \\
\text { Equality of } \\
\text { Variances }\end{array}$} & \multicolumn{7}{|c|}{ t-test for Equality of Means } \\
\hline & & \multirow[t]{2}{*}{$\mathrm{F}$} & \multirow[t]{2}{*}{ Sig. } & \multirow[t]{2}{*}{$\mathrm{t}$} & \multirow[t]{2}{*}{ df } & \multirow[t]{2}{*}{$\begin{array}{l}\text { Sig. (2- } \\
\text { tailed) }\end{array}$} & \multirow[t]{2}{*}{$\begin{array}{c}\text { Mean } \\
\text { Differen } \\
\text { ce }\end{array}$} & \multirow{2}{*}{$\begin{array}{l}\text { Std. } \\
\text { Error } \\
\text { Differen } \\
\text { ce }\end{array}$} & \multicolumn{2}{|c|}{$\begin{array}{l}\text { 95\% Confidence } \\
\text { Interval of the } \\
\text { Difference }\end{array}$} \\
\hline & & & & & & & & & Lower & Upper \\
\hline \multirow{2}{*}{$\begin{array}{l}\text { Postt } \\
\text { est }\end{array}$} & $\begin{array}{l}\text { Equal variances } \\
\text { assumed }\end{array}$ & 2.639 & .110 & 4.330 & 56 & .000 & 4.172 & .964 & 2.242 & 6.103 \\
\hline & $\begin{array}{l}\text { Equal variances } \\
\text { not assumed }\end{array}$ & & & 4.330 & $\begin{array}{c}54.79 \\
1\end{array}$ & .000 & 4.172 & .964 & 2.241 & 6.104 \\
\hline
\end{tabular}

As the assumption of the homogeneity of variances was met $(F=2.63, p=.110)$, the first row of Table 6 was reported. Based on the obtained results, it was concluded that there was a significant difference between the two groups' means on the posttest $(t(56)=4.33, p=.000$, eta squared $=.25$ representing a large effect size $)$. That is, the instruction of MS had a significantly better impact on participants' RC. It should be noted that the assumption of homogeneity of variances was met $(F=2.63, p=.110)$. That is why the first row of Table 6 was reported. Figure 1 demonstrates the mean of RC scores of the participants in the two experimental groups, before and after receiving the treatments.

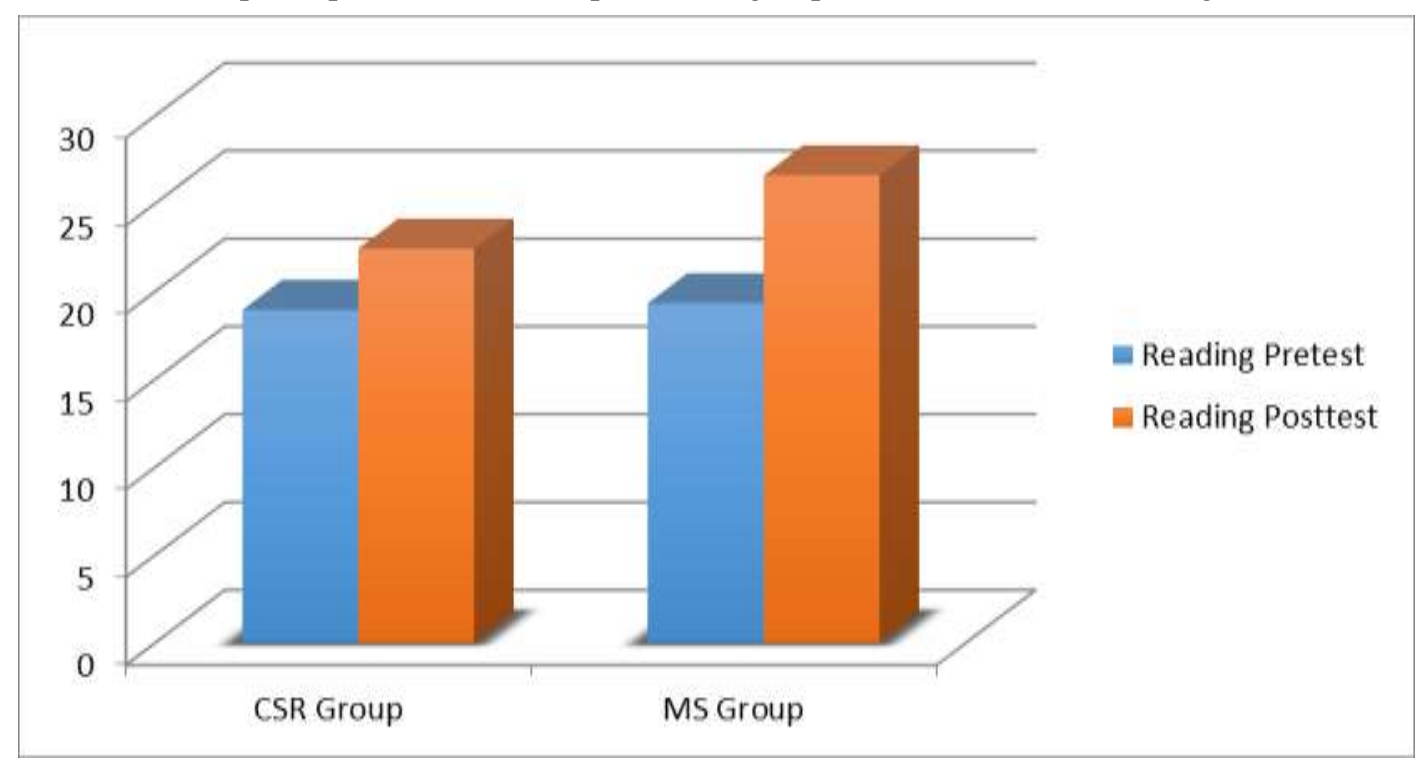

Figure 1. Pretest and posttest scores in the experimental groups 


\section{Discussion}

Considering the significance of RC in ELT domain and developing EFL learners' language skills (Lightbown \& Spada, 2013), ELT researchers and practitioners have been engaged in finding effective reading instruction techniques and strategies for developing RC (Erten \& Topkaya, 2009; Nosratinia et al., 2013). Numerous studies have confirmed the significant development of RC as a result of employing CSR (Katims \& Harmen, 2000; Nosratinia et al., 2013) and MS (Huang \& Newbern, 2012). However, prior to this study, it was not clear which one of these two sets of strategies is more advantageous for developing EFL learners' RC. Based on this premise, this quasi-experimental study attempted to systematically compare the impact of CSR and MS on EFL learners' RC.

As the pre-treatment homogeneity of the participants in the two experimental groups in terms of RC was confirmed, the parametric independent-samples $t$-test was run, after checking the preliminary assumptions, in order to answer the research question. The obtained results revealed that there was a significant difference between the two groups' means on the posttest. More specifically, the impact of MS on participants' RC was significantly higher than the impact of CSR. It should be stated that in this study, two different PET tests were employed in order to eliminate the factor of test familiarity which would affect participants' performance on any subsequent similar test (Best \& Kahn, 2006).

The abovementioned finding provides systematic support for the advantage of Anderson's (2002) MS model over Klingner and Vaughn's (1998) CSR model regarding developing EFL learners' RC. However, there are some points which should be considered while interpreting this result. First and foremost, the current trend in ELT pedagogy is immensely in favor of collaborative activities among EFL learners (Nosratinia \& Zaker, 2013, 2014, 2015), somehow reflected in CSR. On the other hand, culture is believed to play a major role in the way L2 is mastered (Zaker, 2016). Furthermore, there have always been concerns if collaborative activities are necessarily compatible with ELT practice in all contexts and for different cultures. Knowing that many of Iranian EFL learners, based on their cultural beliefs and upbringings, are not really interested in collaborative activities (Amirkhiz, Bakar, Mahmoudi, 2013), it can be legitimate to state that the significance of MS over CSR, as reported in this study, might have been contributed to, at least to some extent, by participants' cultural beliefs and the peculiarities of the context.

When it comes to working on human beings' mental constructs, including language proficiency, a myriad of internal factors might influence how an individual learns and masters new skills (Fahim \& Zaker, 2014; Mitchell \& Myles, 2004; Nosratinia, Zaker, \& Saveiy, 2015; Zaker, 2015). Consequently, in ELT studies, there is always the chance that our estimation of the levels of language skills and the pedagogical advantage of different treatments be inaccurate. Put another way, these internal factors might always function as intervening variables in language studies. Consequently, the advantage of MS over CSR, as observed in this study, might have been influenced by the characteristics of the participants not considered or controlled, e.g. personality type, learning style, creativity, and intelligence. Another factor which might have affected the findings is the length of the treatment. According to Nosratinia and Zaker (2017), the complex characteristics of humans need high levels of manipulation in order to be influenced by an instructor or treatment. Consequently, a longer treatment phase could result in obtaining different results.

\section{Conclusion}

The present study aimed at systematically investigating the impact of teaching CSR and MS on EFL learners' RC. In recent years, the ELT domain has paid more attention to RC, its significance in mastering all language skills, and finding effective instructions and strategies for developing it (Erten \& Topkaya, 2009; Nosratinia et al., 2013). Using a quasi-experimental design, this study considered RC the dependent variable, CSR and MS the modalities of the independent variable, being treatment, and the level of participants the control variable.

Investigating the post-treatment performance of the participants revealed that the MS group outperformed the CSR group in terms of RC. That is, EFL learners would benefit more from focusing on MS, rather than CSR, when RC is concerned. However, as stated in the previous section (see Discussion), the contextual and learner factors should be considered when attempting to generalize the findings. All in all, based on the obtained results and considering the limitations and peculiarities of this study, the researchers came up with the following conclusions:

a) The explicit MS training makes a more significant contribution to EFL learners' RC, compared to CSR.

b) Employing strategies in ELT practice is not only beneficial for elementary level learners.

c) Collaborative activities and strategies are not always better for achieving pedagogical goals. It is important to see a bigger picture in which the internal, personal, and contextual factors are given careful attention.

Considering the obtained results, EFL teachers are suggested to improve their awareness of different strategies, especially RC strategies as this is a problem in many ELT contexts (Finkbeiner \& Svalberg, 2015). Mastering MS implementation is something that would enable EFL teachers to transfer this knowledge to EFL learners and prepare the learners for facing authentic language and get involved in functional tasks. At the other end of the spectrum, EFL learners should become familiar with different strategies for tackling learning problems in different situations (Wilawan, 2013). More specifically, learning and implementing MS would enable EFL learners to function more autonomously and independently when employing the L2 and functioning in EFL contexts. They are also suggested to employ MS when engaged in extensive reading and real world tasks.

Finally, and importantly, syllabus designers and curriculum developers should infuse strategies into materials for comprehending the knowledge embedded in the written texts. In doing so, it is suggested to introduce Anderson's (2002) model through explicit instruction and providing examples. EFL syllabi should also provide strategy instruction guidelines for EFL teachers so that EFL learners would master strategy use faster. It is also suggested to integrate MS 
into prognostic and achievement tests so that the obtained test results would function as a diagnostic tool for developing learners' strategy use.

Considering the peculiarities of the present study, there are some possible avenues for future research. First, other studies can employ other MS and other frameworks in order to inspect their pedagogical value. Second, it is suggested to inspect the impact of teaching MS through Anderson's (2002) model on other language skills. Third, the impact of strategy instruction on EFL teachers' success can be another desirable area of investigation. Fourth, it is recommended to replicate the same study with a longer treatment phase. Sixth, other studies can be conducted with male participants or with equal numbers of male and female participants. Seventh, other researchers are recommended to employ pure/simple random sampling in order to enhance the validity of the findings. Finally, the same study can be conducted among other levels of language proficiency.

\section{References}

Amirkhiz, S. Y. Y., Bakar, K. A., Baki, R., \& Mahmoudi, L. (2013). Teachers' experiential reflections on Iranian and Malaysian students' collaborative orientations. Asian Social Science, 9(1), 271-277.

Anastasiou, D., \& Griva, E. (2009). Awareness of reading strategy and reading comprehension among poor and good readers. Elementary Education Online, 8(2), 283-297.

Anderson, N. J. (1991). Individual differences in strategy use in second language reading and testing. Modern Language Journal, 75, 460-472. doi: 10.1111/j.1540-4781.1991.tb05384.x

Anderson, N. J. (2002). The role of metacognition in second language teaching and learning. ERIC Digest, April 2002 , 1-7.

Anderson, N. J. (2005). L2 learning strategies. In E. Hinkel (Ed.), Handbook of research in second language teaching and learning (pp. 757-771). Mahwah, NJ: Lawrence Erlbaum.

Best, J. W., \& Kahn, J. V. (2006). Research in education (10 $0^{\text {th }}$ ed.). Boston, MA: Pearson Education, Inc.

Carnine, L., \& Carnine, D. (2004). The interaction of reading skills and science content knowledge when teaching struggling secondary students. Reading \& Writing Quarterly, 20, 203-218. doi: 10.1080/10573560490264134

Chamot, A. U. (2004). Issues in language learning strategy research and teaching. Electronic Journal of Foreign Language Teaching, 1(1), 14-26. doi: 10.7575/ijalel.v.2n.1p.186

Efklides, A. (2006). Metacognition and affect: What can metacognitive experiences tell us about the learning process? Elsevier Ltd, 1, 3-14. doi: 10.1016/j.edurev.2005.11.001

Erten, I. H., \& Topkaya, E. Z. (2009). Understanding tolerance of ambiguity of EFL learners in reading classes at tertiary level. Novitas-ROYAL, 3(1), 29-44.

Fahim, M., \& Zaker, A. (2014). EFL learners' creativity and critical thinking: Are they associated? Humanising Language Teaching, 16(3). Retrieved from http://www.hltmag.co.uk/jun14/mart01.htm

Finkbeiner, C., \& Svalberg, A. (2015). Awareness matters: Language, culture, literacy. New York: Routledge Taylor and Francis.

Fuchs, D., \& Fuchs, L. S. (2005). Responsiveness-to-intervention: A blueprint for practitioners' policymakers, and parents. Teaching Exceptional Children, 38, 57-61.

Grabe, W. (2009). Reading in a second language: Moving from theory to practice. Cambridge: Cambridge University Press.

Griffiths, C. (Ed.). (2008). Lessons from good language learners. Cambridge, UK: Cambridge University Press. doi: 10.1017/CBO9780511497667

Harmer, J. (2007). How to teach writing. Essex: Pearson Longman.

Hauck, M. (2005). Metacognitive knowledge, metacognitive strategies, and CALL. In J. Egbert \& G. Petrie (Eds.), CALL: Research Perspectives (pp. 65-86). New Jersey: Lawrence Erlbaum.

Huang, J., \& Newbern, C. (2012). The effects of metacognitive reading strategy instruction on reading performance of adult ESL learners with limited English and literacy skills. Journal of Research and Practice for Adult Literacy, 1(2), 66-77.

Katims, D. S., \& Harmen, J. M. (2000). Strategic instruction in middle school social studies: Enhancing academic and literary outcomes for at-risk students. Intervention in School and Clinic, 35(5), 280-89. doi: 10.1177/105345120003500504

Klingner, J. K., \& Vaughn, S. (1998). Using Collaborative Strategic Reading. Teaching Exceptional Children Journal. 1, 32-37. doi: 10.1177/004005999803000607

Klingner, J. K., \& Vaughn, S. (2000). The helping behaviors of fifth-graders while using collaborative strategic reading (CSR) during ESL content classes. TESOL Quarterly, 34, 69-98. doi: 10.2307/3588097

Klingner, J. K. Vaughn, S., \& Schumm, J. S. (2001). Collaborative Strategic Reading during social studies in heterogeneous fourth grade classrooms. Elementary School Journal. 2(5), 123-45.

Latham-Koenig, Ch., Oxenden, C., \& Seligson, P. (2014). American English file (2nd ed.). Oxford: Oxford University Press. 
Lehr, F., Osborn, J. \& Hiebert, E. H. (2005). A focus on comprehension. Honolulu, HI: Pacific Resources for Education and Learning.

Lightbown, P., \& Spada, N. (2013). How languages are learned (4th ed.). Oxford: Oxford University Press.

McNamara, D. S. (2007). Reading comprehension strategies: Theories, interventions, and technologies. New York: Lawrence Erlbaum Associates, Inc.

Mitchell, R., \& Myles, F. (2004). Second language learning theories (2nd ed.). London: Edward Arnold.

Murphy, P. K., Wilkinson, I. A. G., Soler, A. O., Hennessey, M. N., \& Alexander, J. F. (2009). Examining the effect of classroom discussion on students' comprehension of text: A meta-analysis. Journal of Educational Psychology, 101, 740-64. doi: 10.1037/a0015576

Nosratinia, M., Ghavidel, S., \& Zaker, A. (2015). Teaching metacognitive strategies through Anderson's model: Does it affect EFL learners' listening comprehension? Theory and Practice in Language Studies, 5(6), 1233-1243. doi: $10.17507 /$ tpls.0506.16

Nosratinia, M., Mirzakhani, E., \& Zaker, A. (2013). Toward a humanistic instruction: Collaborative strategic reading approach and EFL learners' reading comprehension. International Journal of Advanced Studies in Humanities and Social Science, 1(8), 1119-1138.

Nosratinia, M., \& Zaker, A. (2013, August). Autonomous learning and critical thinking: Inspecting the association among EFL learners. Paper presented at the First National Conference on Teaching English, Literature, and Translation, Shiraz University, Shiraz, Iran. Retrieved from http://www.civilica.com/Paper-TELT01-TELT01_226.html

Nosratinia, M., \& Zaker, A. (2014). Metacognitive attributes and liberated progress: The association among second language learners' critical thinking, creativity, and autonomy. SAGE Open, 4(3), 1-10. doi: 10.1177/2158244014547178 Nosratinia, M., \& Zaker, A. (2015). Boosting autonomous foreign language learning: Scrutinizing the role of creativity, critical thinking, and vocabulary learning strategies. International Journal of Applied Linguistics and English Literature, 4(4), 86-97. doi: 10.7575/aiac.ijalel.v.4n.4p.86

Nosratinia, M., \& Zaker, A. (2017). Scrutinizing the impact of teachers' critical thinking and teaching autonomy on their teaching success and learners' use of language learning strategies. Journal of Language Teaching and Research, 8(1), 122-132. doi: 10.17507/jltr.0801.15.

Nosratinia, M., Zaker, A., \& Saveiy, M. (2015). Higher-order thinking and individualized learning: Metacognitive awareness and self-efficacy among EFL learners. The Iranian EFL Journal, 11(1), 189-207.

O'Malley, J. M., \& Chamot, H. U., (1990). Language strategies in second language acquisition. Cambridge: Cambridge University Press. doi: 10.1017/CBO9781139524490

O'Malley, J. M., Chamot, A. U., Stewner-Manzanares, G., Kupper, L., \& Russo, R. P. (1985). Learning strategies used by beginning and intermediate ESL students. Language Learning, 35, 21-46. doi: 10.1111/j.1467-1770.1985.tb01013.x Oxford, R. L. (1990). Language learning strategies: What every teacher should know. New York: Newbury House.

Ozgungor, S., \& Guthrie, J. T. (2004). Interactions among elaborative interrogation, knowledge, and interest in the process of constructing knowledge from text. Journal of Educational Psychology, 96, 437-443. doi: 10.1037/00220663.96.3.437

Palincsar, A. S, \& Brown, A. L. (1984). Reciprocal teaching of comprehension fostering and comprehensionmonitoring activities. Cognition and Instruction, 1, 117-175. doi: 10.1207/s1532690xci0102_1

Quintana, J. (2008). PET practice tests. Oxford: Oxford University Press.

Rashtchi, M., \& A. Keyvanfar. (2010). ELT: Quick 'n' easy. Tehran: Rahnama Press.

Standish, L. G. (2005). The effects of collaborative strategic reading and direct instruction in persuasion on sixth-grade students' persuasive writing and attitudes (Unpublished doctoral dissertation) University of Maryland, Maryland, USA.

Tabachnick, B. G., \& Fidell, L. S. (2007). Using multivariate statistics (5th ed.). Boston, MA: Allyn \& Bacon.

Tsao, F. F. (2004). Breaking the point of the difficulty of teaching English in Taiwan by applying reading education. Journal of English Teaching \& Learning, 28(3), 1-16.

Vaughn, S., \& Klingner, J. K. (1999). Teaching reading comprehension through collaborative strategic reading. Intervention in school and clinic, 34(5), 284-292. doi: 10.1177/105345129903400505

Wang, T.H. (2008). The effect of modified collaborative strategic reading on EFL learners' reading comprehension (Unpublished MA thesis) National Changhua University of Education, Changhua, Taiwan.

Wong, B. Y. L. (1985). Self-questioning instructional research: A review. Review of Educational Research, 55(2), 227268. doi: $10.3102 / 00346543055002227$

Wilawan, S. (2013). Enhancing EFL readers' metacognition. Journal of Education and Practice, 4(12), 64-72.

Zahedi, K., \& Dorrimanesh P. (2008). Metacognitive learning strategies and academic success of TEFL, M.A. students in distance education. International Journal of Criminology and Sociological Theory. 1(2), 61-176.

Zaker, A. (2015). EFL learners' language learning strategies and autonomous learning: Which one is a better predictor of L2 skills? Journal of Applied Linguistics-Dubai, 1(1), 27-39.

Zaker, A. (2016). Social constructivism and metacognition in an EFL context: Inspecting the contribution of critical thinking to EFL learners' social intelligence. Humanising Language Teaching, 18(6). Retrieved from www.hltmag.co.uk/dec16/index.htm 